Portland State University

PDXScholar

\title{
Sexual Education Pedagogy in the Global South: PubMed Data in the Age of Globalization
}

Grace A. Walker-Stevenson

Portland State University

Follow this and additional works at: https://pdxscholar.library.pdx.edu/honorstheses

Let us know how access to this document benefits you.

\section{Recommended Citation}

Walker-Stevenson, Grace A., "Sexual Education Pedagogy in the Global South: PubMed Data in the Age of Globalization" (2017). University Honors Theses. Paper 429.

https://doi.org/10.15760/honors.425

This Thesis is brought to you for free and open access. It has been accepted for inclusion in University Honors Theses by an authorized administrator of PDXScholar. Please contact us if we can make this document more accessible: pdxscholar@pdx.edu. 


\title{
Sexual Education Pedagogy in The Global South: \\ PubMed Data in the Age of Globalization
}

by

\author{
Grace Walker- Stevenson
}

\begin{abstract}
An undergraduate honors thesis submitted in partial fulfillment of the
requirements for the degree of

Bachelor of Arts

in

University Honors

and

Sociology
\end{abstract}

Thesis Adviser

Dr. Richard Lockwood

Portland State University 
Abstract

This systematic review and subsequent analysis examines the harm caused by inadequate sexual education in countries with minimal access to healthcare. This review relies on PubMed as its singular database. PubMed is a free search engine that utilizes the MEDLINE database of references on life sciences and biomedical topics. This database is maintained by The United States Library of Medicine and The National Institutes of Health, therefore it is an authoritative entity on the subject of health research. Assessing the breadth of knowledge represented in PubMed related to this issue can be extrapolated to estimate the current state of salient knowledge within The United States Library of Medicine and The National Institutes of Health. The bulk of this review explores the current state of knowledge on the relationship between development and relative burden of disease, with a specific focus on the Human Immunodeficiency Virus and Acquired Immunodeficiency Syndrome, hereon referred to as HIV/AIDS. Search results were filtered for the sub-saharan African region, due to its relative poverty and development status within a globalized system. Adolescents age thirteen to eighteen are the age cohort chosen for this study, with the intention of exploring the risks associated with sexual education during the formative years of sexual identity development. The analysis addresses world systems theory and healthcare in a globalized society. 
Introduction

When conceptualizing health inequality, we tend to think on individual terms. Lifestyle choices and circumstance or bad luck are often the ways in which we parse the fragility of our own biology as we move through social spaces. (Conrad, Leiter ${ }^{2013}$ ) However, public health researchers and epidemiologists know that there are many determining factors for health inequity, some of which have to do with larger socioeconomic structures outside of our individual control. Michael Marmot, president of the World Medical Association, revealed the social injustice underpinning health outcomes in The Whitehall Studies. This groundbreaking research demonstrated a link between health outcomes and social status dispersed in a gradient. This social gradient of health showed that disparities of wealth and power had a direct influence on health outcomes. (Marmot ${ }^{2016}$ )

For the purposes of this research, the qualities of comprehensive sexual health education will be defined using the standards of The United Nations Population Fund, a major organization promoting comprehensive sexual education interventions in African nations. The UNFPA definition includes scientifically accurate information about human anatomy and reproductive health, contraception, childbirth, and sexually transmitted infections- including HIV/AIDS. Additionally, comprehensive sexual education includes information about human rights, gender equality, and coercion or sexual abuse. (UNFPA ${ }^{1995}$ )

Before exploring the necessity of health education as a comprehensive component of modern healthcare, it is worthwhile to illuminate the statistics of the HIV/AIDS crisis in sub-saharan Africa. The Library of Congress classifies sub-saharan Africa as the following 
countries: Angola, Benin, Botswana, Burkina Faso, Burundi, Cameroon, Cape Verde, Central African Republic, Chad, Comoros, Congo (Brazzaville), Congo (Democratic Republic), Côte d'Ivoire, Djibouti, Equatorial Guinea, Eritrea, Ethiopia, Gabon, The Gambia, Ghana, Guinea, Guinea-Bissau, Kenya, Lesotho, Liberia, Madagascar, Malawi, Mali, Mauritania, Mauritius, Mozambique, Namibia, Niger, Nigeria, Réunion, Rwanda, Sao Tome and Principe, Senegal, Seychelles, Sierra Leone, Somalia, South Africa, Sudan, Swaziland, Tanzania, Togo, Uganda, Western Sahara, Zambia, and Zimbabwe. According to the UN-AIDS Prevention Gap Report of 2016, there are 16 million people living with HIV in Eastern and Southern Africa. There is a 7.1\% adult prevalence rate in the region with 960,000 new infections per year and 470,000 AIDS-related deaths per year. $56 \%$ of the population in this region knows their HIV status and $54 \%$ are on antiretroviral treatment. This region is home to over $50 \%$ of the global HIV positive population. South Africa accounted for $40 \%$ of sub-saharan Africa's new infections in 2015, with another 50\% occurring in eight countries: Ethiopia, Kenya, Malawi, Mozambique, Uganda, Tanzania, Zambia and Zimbabwe. This disease is known to disproportionately affect young women, ages 15-24. Other high-risk populations for HIV contraction include sex workers and men who have sex with men. In Botswana, for example, the prevalence rate of HIV among sex workers is $61.9 \%$ compared to the general population rate of $22.2 \%$. (UN-AIDS ${ }^{2016}$ )

Of course, this crisis is multidimensional and exploring the saliency of comprehensive sexual education only addresses one small piece of a much larger set of concerns regarding development and the spread of disease. The HIV/AIDS crisis can be contextualized by the development crisis within sub-saharan Africa that prevents access to healthcare resources and labor. According to research published in the Scandinavian Journal of Public Health, the size of 
public health spending does not independently predict some health outcomes like the infant mortality rate. In low-income countries, the primary determining factor of infant mortality rate appears to be female illiteracy. In middle-income countries, the primary determining factor is income inequality or Gross National Income per capita. Meanwhile, in high income countries, neither of these indicators are the primary factor. (Schell, Reilly, Rosling et al. ${ }^{2007}$ ) This means that the relative importance of health determinants varies between country income levels. Furthermore, that extrapolating the efficacy of a singular policy across the socioeconomic stratification of different countries is ineffective legislative praxis. This also justifies the choice to study education quality as a health determinant in sub-saharan African countries, because female literacy rate is a major determining factor in health. While this review does not address literacy rate directly, it does explore the quality of sexual health education as a health determinant.

It is also necessary to address global stratification as a means for understanding global poverty. Two influential theories of development are dependency theory and world systems theory. Dependency theory focuses on the relationships between poor and wealthy countries, noting the goal of increasing wealth is shared across the development spectrum. However, dependency theory is far too simplistic in that it blames lower income countries for their poverty, failing to recognize the stratified nature of wealth or the postcolonial power dynamics at play in wealth accrual. Dependency theory tends to operate at the level of neoliberal capitalism, believing in the power of the market to determine a rational social order. The difference between this and World Systems theory is that World Systems theory explains that wealthy countries are dependent on the cheap labor and material resources of poorer, countries in order to produce 
goods and maximize profit. This is where the concept of commodity chains is helpful.

Commodity chains conceptualize how wealth is distributed between the poor countries that are stripped of their resources, and the wealthy countries that are able to sell a final product made of those resources for the most profit. (Jacobsen ${ }^{2014}$ ) This is helpful for understanding both the way the economies of the global south are trapped in debt cycles and how their environments are stripped of material resources.

This theory can be further contextualized by the work of Philip McMichael, as his theories build a timeline of the global economy from initial post-colonial infrastructure through the so-called "globalization decade" of structural adjustment. His argument is that there can only be a select number of core countries and that all other countries must compete as part of the commodity chains. This concept that wealth flows to the center and that the former colonial powers see the greatest return on the labor and environmental resources of the global south is the foundation of this analysis. Another example is the way in which Africa has been especially vulnerable to our dependence on slave labor. Africa is a continent rich in natural resources, making its land highly desirable to foreign developers who engage in land-grabbing for agricultural and commercial means. (McMichael ${ }^{2017}$ ) This relates to healthcare systems and ultimately disease spread because it means that the developed world is able to protect its populace from disease outbreak by having well-structured health and education systems. Meanwhile, those on the periphery of the commodity chains are left in a development crisis that makes public infrastructure sparse and underfunded. (McMichael ${ }^{2017}$ ) In Botswana, there are .34 physicians per one thousand people and in Uganda, there are .12 physicians per one thousand 
people, both as of 2010. For comparison, the United States has 2.41 physicians per one thousand people in the same year. (World Bank ${ }^{2017}$ )

According to a study conducted by the Infectious Disease Society of America, providing access to healthcare and preventive medicine is a challenge in sub-saharan Africa. Laboratory testing is especially expensive and though not optimal; it is still crucial to diagnose. However, most of the funding in sub-saharan Africa is allocated to preventive care, with little for laboratory testing. Reliable diagnostic testing is undervalued or otherwise severely limited, therefore inadequate treatment and increased mortality is frequently the result. Often, laboratory expenditures and some general healthcare expenditures are prohibitively expensive for many African countries. (Petti, Polage, Quinn, et al ${ }^{2006}$ ) This results in harm to the public because the lack of access to medical care (and preventive resources, such as condoms) is a crucial health determinant. This issue of prohibitively expensive resources also translates to sexual health education wherein many countries are not able to afford reproductive health resources and comprehensive training for sexual health educators. This can lead to an incomplete education for some and unfortunately, a pseudo-scientific or religious version of sexual education for others.

The following statistics offer a sampling of several sub-saharan African countries, depicting their relative health and wealth statuses. This paints a picture of countries undergoing various stages of a development crisis, which is typical for most of sub-saharan Africa as a region. (McMichael ${ }^{2017}$ ) For example, there is very little data on early childhood education in Botswana. These statistics illustrate a few different facts about Botswana- primarily that their contraceptive prevalence is fairly low, which contributes to HIV spread. It can be assumed by their gross enrollment that while primary school is a commonality at $87.3 \%$, by the time students 
reach ages $15-24$, they stop attending school. Their female youth literacy rate is $97 \%$ (2008-2012) compared to male youth literacy rate of $93.5 \%$ for the same years. Data on HIV/AIDS prevention knowledge for Botswana is not available. The percentage of Botswana's GDP spent on health is $3.5 \%$ and the percentage spent on education is $7.8 \%$. Botswana's contraceptive prevalence is $52.8 \%$. Their secondary school gross enrollment is $68.3 \%$. Their life expectancy at birth is 47.2 years as of 2012. (UNICEF ${ }^{2013}$ )

The female youth literacy rate for Uganda is $85.5 \%(2008-2012)$ compared to the male youth literacy rate of $89.6 \%$ in the same years. Uganda's data for HIV/AIDS prevention knowledge is ranked as follows: $38.1 \%$ for female comprehensive knowledge, $39.5 \%$ for male comprehensive knowledge. $4 \%$ prevalence for females ages $15-24,2.3 \%$ prevalence for males ages $15-24$. Condom usage among males ages $15-24$ is $47.3 \%$. Finally, Uganda spends $3.2 \%$ of their GDP on education and $2.5 \%$ of their GDP on health. Their contraceptive prevalence for women is $30 \%$ from $2008-2012$. Their life expectancy at birth is 58.7 years. Their secondary school net attendance ratio for males is $16.2 \%$ compared to $18.7 \%$ for females. (2008-2012) (UNICEF ${ }^{2013}$ ) Again, these numbers depict countries struggle to educate and care for their population.

In Uganda, the prevalence of child marriage, by age 18 , is $39.7 \%$. The prevalence of female genital mutilation is $1.4 \%$ and surveys found that $8.7 \%$ of the population shows support for the practice. (UNICEF ${ }^{2013}$ ) These statistics depict a country where gender is a major determining factor of health and status starting from birth. These gender disparities, and the violence against women/girls in this country, are yet another factor to consider when examining the gender bias that might occur in sexual education programs, if such programs even exist. 
In South Africa, the adult prevalence rate for HIV is $17.9 \%$. Among women and girls ages (15-24) is the HIV prevalence rate is $13.9 \%$, which is staggeringly high. The life expectancy for South Africans at birth is 56.3 years. Their contraceptive prevalence is $59.9 \%$. Their rate of child marriage by age 18 is $5.6 \% .15 \%$ of the population has given birth by age 18 . Their upper secondary school gross enrollment ratio is $92.1 \%$. (2008-2012) (UNICEF ${ }^{2013}$ )

These statistics only scratch the surface of the complex social issues that have led to the HIV/AIDS crisis in sub-saharan Africa. While all data can be attributed to reputable institutions, there are significant gaps among countries. Statistical data on certain highly at-risk subpopulations, such as sex workers or LGBTQ people, are simply unavailable. This lack of data could be for several reasons. This could depict a cluster of countries for whom deviance, particularly sexual deviance, is highly stigmatized. It could also be that these countries lack the infrastructure to compile data on these subpopulations. Furthermore, in countries such as Uganda, homosexual activity is criminalized. This is notable because while these statistics allow us to approximate the social determinants of health for the region, there is missing data on some of the people most at-risk for contracting HIV.

HIV is a frequently fatal and currently incurable condition contracted by sexual contact. The spread of HIV/AIDS has a relationship to the efficacy of sexual education policy. In countries where the majority of the population lives in extreme poverty, access to adequate sexual education, healthcare, and even food or clean water can be difficult. Additionally, the rate of malnutrition, diarrhea, malaria, tuberculosis and other ailments can play a role in the viral outbreak of HIV as those with already weakened immune systems are more susceptible. The spread of HIV/AIDS is most effectively managed by safe sexual behavior, especially condom 
usage. If contracted, this lifelong condition can be managed with appropriate doses of antiretrovirals and routine visits to clinicians.

The management and prevention of spread is typically the burden of healthcare providers, however the secondary burden is placed on sexual education providers and public health awareness campaigns. This burden is particularly notable in communities that have patchwork healthcare systems and lesser healthcare funding. A heavier reliance on churches and primary schools, to provide sexual education information, exists in such communities. The purpose of this systematic review is to examine the current state of knowledge surrounding the efficacy of churches and primary schools for the provisional sexual education in places where access to doctors is minimal. The reasoning for this topic lies in the rhetoric of the western world, where a narrative exists that poorer continents like Africa can confidently rely on western nonprofits for aid. While many nonprofits do credible work, the diversity among nonprofits is vast. There are some that might do more harm than good in poorer countries. Specifically, regarding sexual education, nonprofits that conduct religious or missionary work, may not be guided by scientific best practices. In The Protestant Ethic and The Spirit of Capitalism, sociologist Max Weber explains that capitalism creates a culture of individuation, belief in predestination, and promotion of racial and patriarchal hierarchies within a division of labor. (Weber ${ }^{1992}$ ) We can extrapolate from this to the current situation in sub-saharan Africa, if we concede that we participate in a global economic system where wealth flows to the core countries, leaving countries, such as the African nations, on the periphery. This follows with the drain of resources and creates a heavier reliance on Protestant-capitalist culture as a means of navigating social spaces. The continent of Africa has a long history of colonization by multiple powers. Following industrialization, we 
now have the concept of neocolonialism where transnational corporations and banks are able to financially exploit poorer nations. However, one topic that is not frequently discussed in the literature is the culture surrounding colonialism and neocolonialism. Pulling from Jurgen Habermas's concept of colonization of the lifeworld, hegemonic ideology can embed in culture and potentially cause great harm for communities. We develop social identities and infrastructures that allow those who are at the top of these constructed hierarchies to readily succeed, often at the expense of the oppressed.

One such example would be the Christian missionary organizations from The United States that spread homophobic rhetoric in Uganda and stimulated the proposal of anti-gay legislation in 2009 and passed into law by The Parliament of Uganda in 2014. However, the Constitutional Court of Uganda ruled the act invalid on procedural grounds, in the same year. (BBC News ${ }^{2014}$ ) Should it take into effect, this legislation could sentence people to death or life imprisonment for engaging in homosexual activity. This phenomenon of US Christian groups spreading homophobia in Uganda was documented for Vanguard TV in the 2010 series entitled "Missionaries of Hate." This documentary caused quite a stir in the United States, causing many to link the impending legislation to US-funded Christian groups such as The Family Life Network. (Vanguard ${ }^{2010}$ ) While homophobic legislation has existed in sub-saharan Africa since colonial rule, (The Library of Congress ${ }^{2014}$ ) the strengthening of these laws could be attributed to what sociologist Jurgen Habermas describes as the colonization of the lifeworld. Colonization of the lifeworld occurs when not only is the economy of a country controlled by colonial powers but the very culture of the country is indelibly shaped by hegemonic influence. To further illustrate, it's worthwhile to note the state of African legislation regarding this issue. Countries 
where homosexual acts are punishable by law: Algeria (fines, imprisonment), Angola

(confinement in asylum or workhouse or colony, probation, termination of employment), Benin (fines, imprisonment), Botswana (imprisonment), Burundi (fines, imprisonment), Cameroon (fines, imprisonment), Central African Republic ("Public expressions of love" between persons of the same sex is punishable by fine and imprisonment), Comoros (fines, imprisonment), Congo ("violations of morality" punishable by fines and imprisonment), Eritrea (imprisonment), Ethiopia (imprisonment), Gambia (imprisonment), Ghana (imprisonment), Guinea (fines, imprisonment), Kenya (imprisonment), Lesotho (arrest without warrant, imprisonment), Liberia (imprisonment), Libya (imprisonment), Malawi (imprisonment), Mauritania (death by stoning, imprisonment, fines), Mauritius (imprisonment), Mozambique (confinement in asylum or workhouse or colony, imprisonment), Nigeria (imprisonment, possible death penalty), Senegal (imprisonment), Sierra Leone (imprisonment), Somalia (imprisonment, public surveillance, deportation), South Sudan (fines, imprisonment), Sudan (flogging, fines, imprisonment, death penalty), Tanzania (imprisonment), Togo (fines, imprisonment), Tunisia (fines, imprisonment), Uganda (imprisonment), Zambia (imprisonment), Zimbabwe (male-only imprisonment, fines). (Library of Congress ${ }^{2014}$ )

Lack of healthcare and education infrastructure makes impoverished countries such as those in sub-saharan Africa especially vulnerable to missionary nonprofits such as those that routinely visit Uganda. The review examines the knowledge about disease risk tied to lack of comprehensive sexual education. Abstinence-only sex education can lead to a pervasive belief in conspiracy theories and religious propaganda surrounding the HIV/AIDS, female sexual health, and LGBTQ identity. (Vanguard ${ }^{2010}$ ) More than merely lacking appropriate sexual health 
information, the promotion of religious ideology as sexual education creates a strong culture of stigma that makes appropriate treatment and resources harder to obtain. Those without access become dependent on religious organizations that promote harmful pseudoscience, which can then lead to unsafe sexual behaviors, discrimination, lack of legislative protections, and ultimately, the spread of HIV/AIDS. A review of the current literature on sexual education's impact on the spread of HIV/AIDS reveals the necessity of promoting comprehensive sexual education in public schools, alongside providing access to adequate reproductive healthcare. This dualistic approach lessens the burden of education on healthcare providers and promotes a needed cultural discourse on the subject of sexual health and HIV/AIDS safety. (Visser ${ }^{2007}$ )

While a systematic literature review cannot fully account for a theoretical interpretation of culture, there is potentially a dearth of scientific knowledge on the harm caused by religious nonprofits in the global south. This review attempts to explore the knowledge that does exist and tie it into a larger theoretical framework for interpretation. The tangible harm these groups cause may manifest in anti-gay legislation, lack of rape protection, and numerous other legal indicators. But does the missionary work of these groups significantly impact disease spread, life expectancy, and similar health indicators? The methodology of these religious education-providers is likely less reliable and scientifically rigorous than the sexual education one might find in a modern hospital or a rigorously-structured public health program. Prior to conducting the search that ultimately structured this review, many previous search algorithms were tried with the goal of looking for specific data on religious organizations, abstinence-only sex education, LGBTQ discrimination, and health outcomes. None of these searches yielded significant or relevant results, suggesting a major gap in the literature. 


\section{Methodology}

The hypothesis of this search was that abstinence-only, religious sex education contributes to the spread of HIV/AIDS. These search terms allowed for the selection of those studies. PubMed is the singular database for this review. The search utilized the following MeSH terms and filters, for specificity. "Religion and sex" OR "sex education" was selected to narrow the field; to select studies that examined the harm of abstinence-only sexual education. "Africa" OR "Uganda” OR “sub-saharan” OR "global south” were selected as search terms in order to narrow the geographic region. Uganda was chosen specifically because of its history of religious sexual education, anti-gay legislation, and evangelical christianity. Originally, Uganda was intended to be the focus of this review, but due to a dearth of information on the subject of evangelical christianity, as it relates to the spread of disease, the search terms were widened. Finally, the following filters were applied to the search algorithm in order to further narrow the field to the appropriate studies. Under the "Article types" filter: "clinical study" OR “comparative study” OR “evaluation studies” OR “meta-analysis” OR “systematic review” were selected in order to include exclusively evidence-based articles. Under the "Language" filter: "English" was selected. Under the "Ages" filter: "Adolescents" was selected, which accounts for people ages thirteen to eighteen. Under the "Publication dates" filter: "10 years" was selected, which accounts for articles published from 2007 to 2017.

The final search algorithm appears as follows:

(((("religion and sex")) OR "sex education")) AND ((africa OR Uganda OR sub-saharan OR global south)) AND

((Clinical Study[ptyp] OR Comparative Study[ptyp] OR Evaluation Studies[ptyp] OR Meta-Analysis[ptyp] OR systematic[sb]) AND "last 10 years"[PDat] AND English[lang] AND adolescent[MeSH]) 
Results

The search algorithm yielded forty articles, which were then narrowed to account for the exclusion criteria: studies that fell outside of the selected adolescent age range (15-24) and studies that fell outside the geographic region of sub-saharan Africa exclusively.

\begin{tabular}{|c|c|c|c|c|}
\hline Identifiers & Authors & Year & Title & Primary Findings \\
\hline $\begin{array}{l}\text { "Comprehensive"* } \\
\text { "Sexual } \\
\text { Education" } \\
\text { "Program Review" } \\
\text { "HIVIAIDS" } \\
\text { "Secondary } \\
\text { School Education" } \\
\text { *CSEP = } \\
\text { Comprehensive } \\
\text { Sexual Education } \\
\text { Program }\end{array}$ & $\begin{array}{l}\text { Agbemenu, K. } \\
\text { Schlenk, E.A. }\end{array}$ & 2011 & $\begin{array}{l}\text { An integrative } \\
\text { review of } \\
\text { comprehensive } \\
\text { sex education } \\
\text { for adolescent } \\
\text { girls in Kenya. }\end{array}$ & $\begin{array}{l}\text { Five } \\
\text { comprehensive } \\
\text { programs existing } \\
\text { in Kenya. Found } \\
\text { that they are a } \\
\text { valid and effective } \\
\text { intervention } \\
\text { leading to the } \\
\text { reduction of } \\
\text { teenage } \\
\text { pregnancy, } \\
\text { HIVIAIDS, and } \\
\text { STIs. Study } \\
\text { emphasizes the } \\
\text { role of nurses as } \\
\text { both educational } \\
\text { and governmental } \\
\text { advocates. }\end{array}$ \\
\hline $\begin{array}{l}\text { "Sexual } \\
\text { Education" } \\
\text { "Program Review" } \\
\text { "HIVIAIDS" } \\
\text { "Secondary } \\
\text { School Education" }\end{array}$ & $\begin{array}{l}\text { Ajuwon, A.J. } \\
\text { Brieger, W.R. }\end{array}$ & 2007 & $\begin{array}{l}\text { Evaluation of a } \\
\text { school-based } \\
\text { reproductive } \\
\text { health education } \\
\text { program in rural } \\
\text { South Western, } \\
\text { Nigeria. } \\
\text { “A study } \\
\text { comparing the } \\
\text { relative efficacy of } \\
\text { teacher } \\
\text { instructions alone, } \\
\text { peer education } \\
\text { alone, and a } \\
\text { combination of } \\
\text { these two on } \\
\text { reproductive }\end{array}$ & $\begin{array}{l}\text { All groups showed } \\
\text { slight gains in } \\
\text { contraceptive } \\
\text { knowledge, } \\
\text { attitude, and } \\
\text { self-efficacy. } \\
\text { Greatest gains for } \\
\text { groups exposed to } \\
\text { multiple education } \\
\text { interventions. }\end{array}$ \\
\hline
\end{tabular}




\begin{tabular}{|c|c|c|c|c|}
\hline & & & $\begin{array}{l}\text { health knowledge, } \\
\text { attitude, perceived } \\
\text { self-efficacy and } \\
\text { sexual practices } \\
\text { among secondary } \\
\text { schools students." }\end{array}$ & \\
\hline $\begin{array}{l}\text { "Sexual } \\
\text { Education" } \\
\text { "Program Review" } \\
\text { "HIVIAIDS" } \\
\text { "Secondary } \\
\text { School Education" }\end{array}$ & $\begin{array}{l}\text { Amaugo, L.G. } \\
\text { Papadopoulos, C. } \\
\text { Ochieng, B.M. } \\
\text { Ali, N. }\end{array}$ & 2014 & $\begin{array}{l}\text { The } \\
\text { effectiveness of } \\
\text { HIV/AIDS } \\
\text { school-based } \\
\text { sexual health } \\
\text { education } \\
\text { programmes in } \\
\text { Nigeria: a } \\
\text { systematic } \\
\text { review. }\end{array}$ & $\begin{array}{l}\text { "Primary literature } \\
\text { published } \\
\text { between January } \\
2002 \text { and May } \\
2012 \text {, which } \\
\text { measured sexual } \\
\text { health outcomes } \\
\text { among } \\
\text { school-based } \\
\text { Nigerians before } \\
\text { and after a sexual } \\
\text { health education } \\
\text { programme was } \\
\text { delivered, was } \\
\text { identified. All } \\
\text { seven studies that } \\
\text { met the inclusion } \\
\text { and exclusion } \\
\text { criteria showed } \\
\text { there had been } \\
\text { positive changes } \\
\text { in outcomes } \\
\text { following these } \\
\text { educational } \\
\text { programmes. } \\
\text { These included } \\
\text { increased } \\
\text { knowledge, } \\
\text { healthier attitudes } \\
\text { and safer sexual } \\
\text { health behaviour. } \\
\text { However, these } \\
\text { studies each had } \\
\text { methodological } \\
\text { flaws which } \\
\text { highlighted a } \\
\text { range of important } \\
\text { design, } \\
\text { implementation } \\
\text { and evaluation } \\
\text { challenges that } \\
\text { future } \\
\text { programmes need } \\
\text { to meet." }\end{array}$ \\
\hline "Sexual & Archibald, T. & 2015 & “They just & Study finds that \\
\hline
\end{tabular}




\begin{tabular}{|c|c|c|c|c|}
\hline $\begin{array}{l}\text { Education" } \\
\text { "Program Review" } \\
\text { "HIVIAIDS" } \\
\text { "Secondary } \\
\text { School Education" } \\
\text { "Evidence-based } \\
\text { programs" } \\
\text { "Non-formal } \\
\text { education" } \\
\text { "Adolescent } \\
\text { sexual health" }\end{array}$ & & & $\begin{array}{l}\text { know": the } \\
\text { epistemological } \\
\text { politics of } \\
\text { "evidence-based } \\
\text { " non-formal } \\
\text { education. }\end{array}$ & $\begin{array}{l}\text { the } \\
\text { implementation of } \\
\text { "evidence-based" } \\
\text { scientific } \\
\text { programs in } \\
\text { Kenya vs the } \\
\text { United States } \\
\text { depicts a model } \\
\text { adapted to make } \\
\text { no mention of the } \\
\text { biomedical } \\
\text { realities of sexual } \\
\text { health. Author } \\
\text { suggests better } \\
\text { integration of } \\
\text { quantitative and } \\
\text { qualitative } \\
\text { methodology to } \\
\text { improve youth } \\
\text { health outcomes. }\end{array}$ \\
\hline $\begin{array}{l}\text { "Sexual } \\
\text { Education" } \\
\text { "HIV Prevention" } \\
\text { "Adolescent } \\
\text { sexual health" }\end{array}$ & $\begin{array}{l}\text { Armistead, L. } \\
\text { Cook, S. } \\
\text { Skinner, D. } \\
\text { Toefy, Y. } \\
\text { Anthony, E.R. } \\
\text { Zimmerman, L. } \\
\text { Salama, C. } \\
\text { Hipp, T. } \\
\text { Goodnight, B. } \\
\text { Chow, L. }\end{array}$ & 2014 & $\begin{array}{l}\text { Preliminary } \\
\text { results from a } \\
\text { family-based HIV } \\
\text { prevention } \\
\text { intervention for } \\
\text { South African } \\
\text { youth. }\end{array}$ & $\begin{array}{l}\text { Utilizing } \\
\text { intergenerational } \\
\text { social networks } \\
\text { holds promise for } \\
\text { HIV knowledge } \\
\text { and prevent } \\
\text { among South } \\
\text { African } \\
\text { adolescents. } \\
\text { Parent-youth } \\
\text { communication, } \\
\text { particular in } \\
\text { households with a } \\
\text { primary female } \\
\text { caregiver hold } \\
\text { promise for } \\
\text { implementing } \\
\text { HIVIAIDS } \\
\text { education } \\
\text { interventions. }\end{array}$ \\
\hline $\begin{array}{l}\text { "Sexual } \\
\text { Education" } \\
\text { "HIVIAIDS" } \\
\text { "Knowledge, } \\
\text { attitudes, } \\
\text { behaviors" } \\
\text { "Adolescent } \\
\text { sexual health" } \\
\text { "Sexual risk } \\
\text { behavior" }\end{array}$ & $\begin{array}{l}\text { Brown, M.S. } \\
\text { Sebego, M. } \\
\text { Mogobe, K. } \\
\text { Ntsayagae, E. } \\
\text { Sabone, M. } \\
\text { Seboni, N. }\end{array}$ & 2008 & $\begin{array}{l}\text { Exploring the } \\
\text { HIVIAIDS-related } \\
\text { knowledge, } \\
\text { attitudes, and } \\
\text { behaviors of } \\
\text { university } \\
\text { students in } \\
\text { Botswana. }\end{array}$ & $\begin{array}{l}\text { The purpose of } \\
\text { this study was to } \\
\text { assess the } \\
\text { efficacy of two } \\
\text { institutional } \\
\text { interventions at a } \\
\text { university in } \\
\text { Botswana. } \\
\text { Results found that } \\
\text { while significant } \\
\text { education and }\end{array}$ \\
\hline
\end{tabular}




\begin{tabular}{|c|c|c|c|c|}
\hline & & & & $\begin{array}{l}\text { attitude changes } \\
\text { were made, no } \\
\text { change in sexual } \\
\text { risk behavior was } \\
\text { reported. }\end{array}$ \\
\hline $\begin{array}{l}\text { "Sexual } \\
\text { Education" } \\
\text { "Intervention } \\
\text { Review" } \\
\text { "HIV/AIDS" } \\
\text { "Secondary } \\
\text { School Education" }\end{array}$ & $\begin{array}{l}\text { Cowan, F.M. } \\
\text { Pascoe, S.J. } \\
\text { Langhaug, L.F. } \\
\text { Mavhu, W. } \\
\text { Chidiya, S. } \\
\text { Jaffar, S. } \\
\text { Mbizvo, M.T. } \\
\text { Stephenson, J.M. } \\
\text { Johnson, A.M. } \\
\text { Power, R.M. } \\
\text { Woelk, G. } \\
\text { Hayes, R.J. }\end{array}$ & 2010 & $\begin{array}{l}\text { The Regai Dzive } \\
\text { Shiri project: } \\
\text { results of a } \\
\text { randomized trial } \\
\text { of an HIV } \\
\text { prevention } \\
\text { intervention for } \\
\text { youth. } \\
\text { "Cluster } \\
\text { randomized trial of } \\
\text { community-based, } \\
\text { multicomponent } \\
\text { HIV, and } \\
\text { reproductive } \\
\text { health intervention } \\
\text { aimed at changing } \\
\text { social norms for } \\
\text { adolescents in } \\
\text { rural Zimbabwe." }\end{array}$ & $\begin{array}{l}\text { "Despite an } \\
\text { impact on } \\
\text { knowledge, some } \\
\text { attitudes, and } \\
\text { reported } \\
\text { pregnancy, there } \\
\text { was no impact of } \\
\text { this intervention } \\
\text { on HIV or HSV-2 } \\
\text { prevalence, } \\
\text { further evidence } \\
\text { that behavioral } \\
\text { interventions } \\
\text { alone are unlikely } \\
\text { to be sufficient to } \\
\text { reverse the HIV } \\
\text { epidemic. The } \\
\text { challenge remains } \\
\text { to find effective } \\
\text { HIV prevention } \\
\text { approaches for } \\
\text { young people in } \\
\text { the face of } \\
\text { continued and } \\
\text { unacceptably high } \\
\text { HIV incidence, } \\
\text { particularly among } \\
\text { young women." }\end{array}$ \\
\hline $\begin{array}{l}\text { "Sexual } \\
\text { Education" } \\
\text { "Intervention } \\
\text { Review" } \\
\text { "HIVIAIDS" } \\
\text { "Secondary } \\
\text { School Education" } \\
\text { "Comprehensive } \\
\text { Sexual education" }\end{array}$ & $\begin{array}{l}\text { Doyle, A.M. } \\
\text { Weiss, H.A. } \\
\text { Maganja, K. } \\
\text { Kapiga, S. } \\
\text { McCormack, S. } \\
\text { Watson-Jones, D. } \\
\text { Changalucha, J. } \\
\text { Hayes, R.J. } \\
\text { Ross, D.A. }\end{array}$ & 2011 & $\begin{array}{l}\text { The long-term } \\
\text { impact of the } \\
\text { MEMA kwa } \\
\text { Vijana } \\
\text { adolescent } \\
\text { sexual and } \\
\text { reproductive } \\
\text { health } \\
\text { intervention: } \\
\text { effect of dose } \\
\text { and time since } \\
\text { intervention } \\
\text { exposure. }\end{array}$ & $\begin{array}{l}\text { Impact on } \\
\text { knowledge and } \\
\text { attitudes occurred } \\
\text { across all } \\
\text { sub-groups, which } \\
\text { suggests that } \\
\text { long-term } \\
\text { exposure to the } \\
\text { intervention } \\
\text { program is } \\
\text { effective and } \\
\text { program should } \\
\text { be expanded. } \\
\text { Despite } \\
\text { knowledge and } \\
\text { attitude changes, } \\
\text { HIV prevalence } \\
\text { was not impacted. }\end{array}$ \\
\hline
\end{tabular}




\begin{tabular}{|c|c|c|c|c|}
\hline $\begin{array}{l}\text { "Religion" } \\
\text { "Islam" } \\
\text { "Sexual } \\
\text { Education" } \\
\text { "Intervention } \\
\text { Review" } \\
\text { "HIVIAIDS" } \\
\text { "Secondary } \\
\text { School Education" } \\
\text { "Comprehensive } \\
\text { Sexual education" } \\
\text { "Sexual risk } \\
\text { behavior" }\end{array}$ & Gilbert, S.S. & 2008 & $\begin{array}{l}\text { The influence of } \\
\text { Islam on AIDS } \\
\text { prevention } \\
\text { among } \\
\text { Senegalese } \\
\text { university } \\
\text { students. }\end{array}$ & $\begin{array}{l}\text { Senegal has the } \\
\text { lowest prevalence } \\
\text { rate of HIVIAIDS } \\
\text { in sub-saharan } \\
\text { Africa. Study } \\
\text { inquired whether } \\
\text { religiosity } \\
\text { impacted sexual } \\
\text { risk behaviors and } \\
\text { drug use. More } \\
\text { religious persons } \\
\text { were more likely } \\
\text { to abstain from } \\
\text { sex, however they } \\
\text { were not more } \\
\text { likely to use } \\
\text { condoms when } \\
\text { sexually active. }\end{array}$ \\
\hline $\begin{array}{l}\text { "Sexual } \\
\text { Education" } \\
\text { "HIV Prevention" } \\
\text { "Adolescent } \\
\text { sexual health" }\end{array}$ & $\begin{array}{l}\text { Helleve, A. } \\
\text { Flisher, A.J. } \\
\text { Onya, H. } \\
\text { Kaaya, S. } \\
\text { Mukoma, W. } \\
\text { Swai, C. } \\
\text { Klepp, KI. }\end{array}$ & 2009 & $\begin{array}{l}\text { Teachers' } \\
\text { confidence in } \\
\text { teaching } \\
\text { HIVIAIDS and } \\
\text { sexuality in } \\
\text { South African } \\
\text { and Tanzanian } \\
\text { schools. }\end{array}$ & $\begin{array}{l}\text { Study rating } \\
\text { teacher } \\
\text { confidence in } \\
\text { dispensing } \\
\text { comprehensive } \\
\text { sexual education } \\
\text { and HIV } \\
\text { prevention } \\
\text { knowledge. } \\
\text { Tanzanian } \\
\text { teachers found to } \\
\text { be more confident } \\
\text { than South African } \\
\text { teachers. } \\
\text { Suggests need for } \\
\text { implementing } \\
\text { more structured } \\
\text { program. }\end{array}$ \\
\hline $\begin{array}{l}\text { "Sexual } \\
\text { Education" } \\
\text { "HIV Prevention" } \\
\text { "Adolescent } \\
\text { sexual health" } \\
\text { "Evidence based } \\
\text { intervention" }\end{array}$ & $\begin{array}{l}\text { Jemmott, L.S. } \\
\text { Jemmott, J.B. 3rd. } \\
\text { Ngwane, Z. } \\
\text { Icard, L. } \\
\text { O'Leary, A. } \\
\text { Gueits, L. } \\
\text { Brawner, B. }\end{array}$ & 2014 & $\begin{array}{l}\text { 'Let Us Protect } \\
\text { Our Future' a } \\
\text { culturally } \\
\text { congruent } \\
\text { evidenced-based } \\
\text { HIV/STD } \\
\text { risk-reduction } \\
\text { intervention for } \\
\text { young South } \\
\text { African } \\
\text { adolescents. }\end{array}$ & $\begin{array}{l}\text { Using social } \\
\text { cognitive theory, a } \\
\text { risk-reduction } \\
\text { intervention was } \\
\text { implemented } \\
\text { targeting South } \\
\text { African } \\
\text { adolescents. } \\
\text { Study found } \\
\text { significant } \\
\text { decrease in } \\
\text { self-reported } \\
\text { sexual risk } \\
\text { behaviors } \\
\text { compared with a }\end{array}$ \\
\hline
\end{tabular}




\begin{tabular}{|c|c|c|c|c|}
\hline & & & & $\begin{array}{l}\text { control } \\
\text { intervention. }\end{array}$ \\
\hline $\begin{array}{l}\text { "Sexual } \\
\text { Education" } \\
\text { "HIV Prevention" } \\
\text { "Adolescent } \\
\text { sexual health" } \\
\text { "Evidence based } \\
\text { intervention" } \\
\text { "Sexual risk } \\
\text { behavior" }\end{array}$ & $\begin{array}{l}\text { Jewkes, R. } \\
\text { Nduna, M. } \\
\text { Levin, J. } \\
\text { Jama, N. } \\
\text { Dunkle, K. } \\
\text { Puren, A. } \\
\text { Duvvury, N. }\end{array}$ & 2008 & $\begin{array}{l}\text { Impact of } \\
\text { stepping stones } \\
\text { on incidence of } \\
\text { HIV and HSV-2 } \\
\text { and sexual } \\
\text { behaviour in } \\
\text { rural South } \\
\text { Africa: cluster } \\
\text { randomised } \\
\text { controlled trial. }\end{array}$ & $\begin{array}{l}\text { Assessing the } \\
\text { impact of an HIV } \\
\text { prevention } \\
\text { program on } \\
\text { incidence of HIV } \\
\text { and HSV-2 and } \\
\text { sexual behavior. } \\
\text { Found the } \\
\text { program did not } \\
\text { impact incidence } \\
\text { rate of HIV but did } \\
\text { impact HSV-2 and } \\
\text { intimate partner } \\
\text { violence. }\end{array}$ \\
\hline $\begin{array}{l}\text { "Religion" } \\
\text { "Islam" } \\
\text { "Sexual } \\
\text { Education" } \\
\text { "Intervention } \\
\text { Review" } \\
\text { "HIVIAIDS" } \\
\text { "Secondary } \\
\text { School Education" } \\
\text { "Comprehensive } \\
\text { Sexual education" } \\
\text { "Sexual risk } \\
\text { behavior" }\end{array}$ & $\begin{array}{l}\text { Kagimu, M. } \\
\text { Kaye, S. } \\
\text { Ainomugisha, D. } \\
\text { Lutalo, I. } \\
\text { Walakira, Y. } \\
\text { Guwatudde, D. } \\
\text { Rwabukwali, C. }\end{array}$ & 2012 & $\begin{array}{l}\text { Evidence-based } \\
\text { monitoring and } \\
\text { evaluation of the } \\
\text { faith-based } \\
\text { approach to HIV } \\
\text { prevention } \\
\text { among Christian } \\
\text { and Muslim } \\
\text { youth in Wakiso } \\
\text { district in } \\
\text { Uganda. }\end{array}$ & $\begin{array}{l}\text { Higher degrees of } \\
\text { religiosity seem to } \\
\text { promote higher } \\
\text { rates of } \\
\text { abstinence, } \\
\text { faithfulness in } \\
\text { marriage, and } \\
\text { lower rate of HIV } \\
\text { infection. The } \\
\text { program being } \\
\text { evaluated } \\
\text { employs scientific } \\
\text { information about } \\
\text { HIV/AIDS } \\
\text { alongside } \\
\text { religious material, } \\
\text { which may } \\
\text { account for the } \\
\text { lower rate of risk } \\
\text { behavior. }\end{array}$ \\
\hline $\begin{array}{l}\text { "Comprehensive } \\
\text { Sexual Education" } \\
\text { "Program Review" } \\
\text { "HIVIAIDS" } \\
\text { "Secondary } \\
\text { School Education" }\end{array}$ & $\begin{array}{l}\text { Kawai, K. } \\
\text { Kaaya, S.F. } \\
\text { Kajula, L. } \\
\text { Mbwambo, J. } \\
\text { Kilonzo, G.P. } \\
\text { Fawzi, W.W. }\end{array}$ & 2008 & $\begin{array}{l}\text { Parents' and } \\
\text { teachers' } \\
\text { communication } \\
\text { about HIV and } \\
\text { sex in relation to } \\
\text { the timing of } \\
\text { sexual initiation } \\
\text { among young } \\
\text { adolescents in } \\
\text { Tanzania. }\end{array}$ & $\begin{array}{l}\text { Study highlights } \\
\text { the necessity of } \\
\text { responsible adults } \\
\text { in discussing } \\
\text { sexual matters } \\
\text { with adolescents } \\
\text { in sub-saharan } \\
\text { Africa. More } \\
\text { research is } \\
\text { needed to } \\
\text { understand and } \\
\text { improve the } \\
\text { quality of parental } \\
\text { communication. }\end{array}$ \\
\hline
\end{tabular}




\begin{tabular}{|c|c|c|c|c|}
\hline & & & & $\begin{array}{l}\text { Teachers play a } \\
\text { very important } \\
\text { role. }\end{array}$ \\
\hline $\begin{array}{l}\text { "Comprehensive } \\
\text { Sexual Education" } \\
\text { "Program Review" } \\
\text { "Secondary } \\
\text { School Education" }\end{array}$ & $\begin{array}{l}\text { Lutalo, T. } \\
\text { Kigozi, G. } \\
\text { Kimera, E. } \\
\text { Serwadda, D. } \\
\text { Wawer, M.J. } \\
\text { Zabin, L.S. } \\
\text { Gray, R.H. }\end{array}$ & 2010 & $\begin{array}{l}\text { A randomized } \\
\text { community trial } \\
\text { of enhanced } \\
\text { family planning } \\
\text { outreach in } \\
\text { Rakai, Uganda. }\end{array}$ & $\begin{array}{l}\text { Modest impact. } \\
\text { Social marketing } \\
\text { can increase } \\
\text { hormonal } \\
\text { contraceptive use } \\
\text { and decrease } \\
\text { pregnancy rates } \\
\text { but direct } \\
\text { intervention } \\
\text { programs would } \\
\text { likely be more } \\
\text { effective. }\end{array}$ \\
\hline $\begin{array}{l}\text { "Comprehensive } \\
\text { Sexual Education" } \\
\text { "Program Review" } \\
\text { "Secondary } \\
\text { School Education" } \\
\text { "Sexual Risk } \\
\text { Behavior" } \\
\text { "HIVIAIDS" }\end{array}$ & $\begin{array}{l}\text { Mason-Jones, } \\
\text { A.J. Mathews, C. } \\
\text { Flisher, A.J. }\end{array}$ & 2011 & $\begin{array}{l}\text { Can peer } \\
\text { education make } \\
\text { a difference? } \\
\text { Evaluation of a } \\
\text { South African } \\
\text { adolescent peer } \\
\text { education } \\
\text { program to } \\
\text { promote sexual } \\
\text { and reproductive } \\
\text { health. }\end{array}$ & $\begin{array}{l}\text { Study to evaluate } \\
\text { the effectiveness } \\
\text { of a } \\
\text { government-led } \\
\text { peer education } \\
\text { program on } \\
\text { self-reported } \\
\text { sexual health } \\
\text { behavior. No } \\
\text { significant } \\
\text { difference } \\
\text { detected in regard } \\
\text { to condom usage. } \\
\text { The peer } \\
\text { education } \\
\text { program was not } \\
\text { considered } \\
\text { effective. }\end{array}$ \\
\hline $\begin{array}{l}\text { "Comprehensive } \\
\text { Sexual Education" } \\
\text { "Program Review" } \\
\text { "Secondary } \\
\text { School Education" } \\
\text { "HIVIAIDS" } \\
\text { "Intervention } \\
\text { Review" }\end{array}$ & $\begin{array}{l}\text { Mathews, C. } \\
\text { Eggers, S.M. } \\
\text { de Vries, P.J. } \\
\text { Mason-Jones, } \\
\text { A.J. Townsend, L. } \\
\text { Aarø, L.E. } \\
\text { De Vries, H. }\end{array}$ & 2015 & $\begin{array}{l}\text { Reaching the } \\
\text { hard to reach: } \\
\text { longitudinal } \\
\text { investigation of } \\
\text { adolescents' } \\
\text { attendance at an } \\
\text { after-school } \\
\text { sexual and } \\
\text { reproductive } \\
\text { health } \\
\text { programme in } \\
\text { Western Cape, } \\
\text { South Africa. }\end{array}$ & $\begin{array}{l}\text { Special attention } \\
\text { is required to } \\
\text { vulnerable } \\
\text { adolescents and } \\
\text { structural barriers } \\
\text { to program } \\
\text { attendance should } \\
\text { be reduced. } \\
\text { However, } \\
\text { after-school } \\
\text { interventions, } \\
\text { providing support } \\
\text { for adolescents } \\
\text { with mental health } \\
\text { problems and } \\
\text { neurodevelopmen } \\
\text { tal problems has }\end{array}$ \\
\hline
\end{tabular}




\begin{tabular}{|c|c|c|c|c|}
\hline & & & & $\begin{array}{l}\text { proven effective in } \\
\text { dispensing HIV } \\
\text { prevention } \\
\text { knowledge. }\end{array}$ \\
\hline $\begin{array}{l}\text { "Comprehensive } \\
\text { Sexual Education" } \\
\text { "Program Review" } \\
\text { "Secondary } \\
\text { School Education" } \\
\text { "HIVIAIDS" } \\
\text { "Intervention } \\
\text { Review" } \\
\text { "Religion" } \\
\text { "Christian" } \\
\text { "Muslim" }\end{array}$ & $\begin{array}{l}\text { Maticka-Tyndale, } \\
\text { E. } \\
\text { Mungwete, R. } \\
\text { Jayeoba, O. }\end{array}$ & 2014 & $\begin{array}{l}\text { Replicating } \\
\text { impact of a } \\
\text { primary school } \\
\text { HIV prevention } \\
\text { programme: } \\
\text { primary school } \\
\text { action for better } \\
\text { health, Kenya. }\end{array}$ & $\begin{array}{l}\text { Analysis of } \\
\text { small-scale } \\
\text { delivery of } \\
\text { school-based } \\
\text { interventions. } \\
\text { Sample group } \\
\text { was } \\
\text { predominantly } \\
\text { Christian (10\% } \\
\text { Muslim). Results } \\
\text { demonstrated } \\
\text { gains in } \\
\text { knowledge, safe } \\
\text { sexual behavior, } \\
\text { condom usage, } \\
\text { acceptance of } \\
\text { HIV+ students, } \\
\text { and promotion of } \\
\text { HIV-testing } \\
\text { behaviors. }\end{array}$ \\
\hline $\begin{array}{l}\text { "Comprehensive } \\
\text { Sexual Education" } \\
\text { "Secondary } \\
\text { School Education" } \\
\text { "HIVIAIDS" } \\
\text { "Intervention } \\
\text { Review" } \\
\text { "Sexual Risk } \\
\text { Behavior" }\end{array}$ & $\begin{array}{l}\text { Michielsen, K. } \\
\text { Chersich, M.F. } \\
\text { Luchters, S. } \\
\text { De Koker, P. } \\
\text { Van Rossem, R. } \\
\text { Temmerman, M. }\end{array}$ & 2010 & $\begin{array}{l}\text { Effectiveness of } \\
\text { HIV prevention } \\
\text { for youth in } \\
\text { sub-Saharan } \\
\text { Africa: } \\
\text { systematic } \\
\text { review and } \\
\text { meta-analysis of } \\
\text { randomized and } \\
\text { nonrandomized } \\
\text { trials. }\end{array}$ & $\begin{array}{l}\text { Few trials report } \\
\text { biological } \\
\text { outcomes. Study } \\
\text { suggests more } \\
\text { effective } \\
\text { interventions } \\
\text { targeting youth, } \\
\text { exploration of } \\
\text { implementation } \\
\text { difficulties, sex } \\
\text { differences in } \\
\text { response to } \\
\text { interventions. }\end{array}$ \\
\hline $\begin{array}{l}\text { "Comprehensive } \\
\text { Sexual Education" } \\
\text { "Secondary } \\
\text { School Education" } \\
\text { "HIVIAIDS" } \\
\text { "Intervention } \\
\text { Review" } \\
\text { "Sexual Risk } \\
\text { Behavior" }\end{array}$ & $\begin{array}{l}\text { Mukoma, W. } \\
\text { Flisher, A.J. } \\
\text { Ahmed, N. } \\
\text { Jansen, S. } \\
\text { Mathews, C. } \\
\text { Klepp, K.I. } \\
\text { Schaalma H. }\end{array}$ & 2009 & $\begin{array}{l}\text { Process } \\
\text { evaluation of a } \\
\text { school-based } \\
\text { HIVIAIDS } \\
\text { intervention in } \\
\text { South Africa. }\end{array}$ & $\begin{array}{l}\text { Proper } \\
\text { implementation of } \\
\text { the interventions } \\
\text { hindered by large } \\
\text { class sizes, too } \\
\text { many activities in } \\
\text { the interventions, } \\
\text { teacher resistance } \\
\text { to methods, } \\
\text { general disregard } \\
\text { for life orientation } \\
\text { among students. }\end{array}$ \\
\hline
\end{tabular}




\begin{tabular}{|c|c|c|c|c|}
\hline $\begin{array}{l}\text { "Comprehensive } \\
\text { Sexual Education" } \\
\text { "Secondary } \\
\text { School Education" } \\
\text { "HIVIAIDS" } \\
\text { "Intervention } \\
\text { Review" } \\
\text { "Sexual Risk } \\
\text { Behavior" }\end{array}$ & $\begin{array}{l}\text { Ogunfowokan, } \\
\text { A.A. } \\
\text { Fajemilehin, R.B. }\end{array}$ & 2012 & $\begin{array}{l}\text { Impact of a } \\
\text { school-based } \\
\text { sexual abuse } \\
\text { prevention } \\
\text { education } \\
\text { program on the } \\
\text { knowledge and } \\
\text { attitude of high } \\
\text { school girls. }\end{array}$ & $\begin{array}{l}\text { Education is a } \\
\text { significant tool to } \\
\text { improve the } \\
\text { knowledge } \\
\text { associated sexual } \\
\text { abuse and } \\
\text { comprehensive } \\
\text { sexual education } \\
\text { knowledge. }\end{array}$ \\
\hline $\begin{array}{l}\text { "Comprehensive } \\
\text { Sexual Education" } \\
\text { "Secondary } \\
\text { School Education" } \\
\text { "HIVIAIDS" } \\
\text { "Intervention } \\
\text { Review" } \\
\text { "Sexual Risk } \\
\text { Behavior" }\end{array}$ & $\begin{array}{l}\text { Paul-Ebhohimhen, } \\
\text { V.A. } \\
\text { Poobalan, A. } \\
\text { van Teijlingen, } \\
\text { E.R. }\end{array}$ & 2008 & $\begin{array}{l}\text { A systematic } \\
\text { review of } \\
\text { school-based } \\
\text { sexual health } \\
\text { interventions to } \\
\text { prevent STI/HIV } \\
\text { in sub-Saharan } \\
\text { Africa. }\end{array}$ & $\begin{array}{l}\text { Knowledge and } \\
\text { attitudes were the } \\
\text { easiest to } \\
\text { statistically } \\
\text { change with } \\
\text { proper } \\
\text { intervention } \\
\text { methodology. } \\
\text { Study found that } \\
\text { behavioral } \\
\text { changes were } \\
\text { much less likely to } \\
\text { occur, such as } \\
\text { abstinence and } \\
\text { condom usage. } \\
\text { Behavioral } \\
\text { changes were } \\
\text { more influenced } \\
\text { by } \\
\text { pre-intervention } \\
\text { sexual history. }\end{array}$ \\
\hline $\begin{array}{l}\text { "Comprehensive } \\
\text { Sexual Education" } \\
\text { "Secondary } \\
\text { School Education" } \\
\text { "HIVIAIDS" } \\
\text { "Intervention } \\
\text { Review" } \\
\text { "Sexual Risk } \\
\text { Behavior" }\end{array}$ & $\begin{array}{l}\text { Plüddemann, A. } \\
\text { Flisher, A.J. } \\
\text { Mathews, C. } \\
\text { Carney, T. } \\
\text { Lombard, C. }\end{array}$ & 2008 & $\begin{array}{l}\text { Adolescent } \\
\text { methamphetami } \\
\text { ne use and } \\
\text { sexual risk } \\
\text { behaviour in } \\
\text { secondary } \\
\text { school students } \\
\text { in Cape Town, } \\
\text { South Africa. }\end{array}$ & $\begin{array}{l}\text { Research found } \\
\text { significant } \\
\text { associations } \\
\text { between } \\
\text { methamphetamin } \\
\text { e usage in the } \\
\text { past } 12 \text { months } \\
\text { and sexual } \\
\text { activity. Study } \\
\text { recommends that } \\
\text { sexual education } \\
\text { interventions } \\
\text { incorporate the } \\
\text { link between } \\
\text { drugs and STI's in } \\
\text { their prevention } \\
\text { strategies for } \\
\text { adolescents. }\end{array}$ \\
\hline "Comprehensive & Schaalma, $\mathrm{H}$. & 2009 & Correlates of & Higher intentions \\
\hline
\end{tabular}




\begin{tabular}{|c|c|c|c|c|}
\hline $\begin{array}{l}\text { Sexual Education" } \\
\text { "Secondary } \\
\text { School Education" } \\
\text { "HIVIAIDS" } \\
\text { "Intervention } \\
\text { Review" } \\
\text { "Sexual Risk } \\
\text { Behavior" }\end{array}$ & $\begin{array}{l}\text { Aarø, L.E. } \\
\text { Flisher, A.J. } \\
\text { Mathews, C. } \\
\text { Kaaya, S. } \\
\text { Onya, H. } \\
\text { Ragnarson, A. } \\
\text { Klepp, K.I. }\end{array}$ & & $\begin{array}{l}\text { intention to use } \\
\text { condoms among } \\
\text { Sub-Saharan } \\
\text { African youth: } \\
\text { the applicability } \\
\text { of the theory of } \\
\text { planned } \\
\text { behaviour. }\end{array}$ & $\begin{array}{l}\text { of condom usage } \\
\text { correlates with } \\
\text { higher access. } \\
\text { Social cognition } \\
\text { models used to } \\
\text { interpret data. } \\
\text { Typically found } \\
\text { less sexual risk } \\
\text { behavior in those } \\
\text { of higher } \\
\text { socioeconomic } \\
\text { status. }\end{array}$ \\
\hline $\begin{array}{l}\text { "Comprehensive } \\
\text { Sexual Education" } \\
\text { "Secondary } \\
\text { School Education" } \\
\text { "Intervention } \\
\text { Review" } \\
\text { "Sexual Risk } \\
\text { Behavior" }\end{array}$ & $\begin{array}{l}\text { Taylor, M. } \\
\text { Jinabhai, C. } \\
\text { Dlamini, S. } \\
\text { Sathiparsad, R. } \\
\text { Eggers, M.S. } \\
\text { De Vries, H. }\end{array}$ & 2014 & $\begin{array}{l}\text { Effects of a } \\
\text { teenage } \\
\text { pregnancy } \\
\text { prevention } \\
\text { program in } \\
\text { KwaZulu-Natal, } \\
\text { South Africa. }\end{array}$ & $\begin{array}{l}\text { Another attitudinal } \\
\text { study, rather than } \\
\text { biological study. } \\
\text { Research found } \\
\text { significant } \\
\text { increase in } \\
\text { intentions to } \\
\text { abstain from sex } \\
\text { whilst in school, } \\
\text { plans to } \\
\text { communicate with } \\
\text { partners about } \\
\text { teen pregnancy, } \\
\text { and increased } \\
\text { condom usage. } \\
\text { Intervention } \\
\text { program seems } \\
\text { somewhat } \\
\text { effective. }\end{array}$ \\
\hline $\begin{array}{l}\text { "Comprehensive } \\
\text { Sexual Education" } \\
\text { "Secondary } \\
\text { School Education" } \\
\text { "HIVIAIDS" } \\
\text { "Intervention } \\
\text { Review" } \\
\text { "Sexual Risk } \\
\text { Behavior" }\end{array}$ & Visser, M.J. & 2007 & $\begin{array}{l}\text { HIVIAIDS } \\
\text { prevention } \\
\text { through peer } \\
\text { education and } \\
\text { support in } \\
\text { secondary } \\
\text { schools in South } \\
\text { Africa }\end{array}$ & $\begin{array}{l}\text { Program aimed to } \\
\text { provide accurate } \\
\text { information about } \\
\text { HIVIAIDS, peer } \\
\text { group norms, and } \\
\text { establish support } \\
\text { for students. } \\
\text { While the program } \\
\text { did not impact } \\
\text { condom usage, it } \\
\text { did change } \\
\text { perceptions of } \\
\text { perceived peer } \\
\text { activity and } \\
\text { therefore delayed } \\
\text { onset of sexual } \\
\text { activity. Which } \\
\text { can aid HIVIAIDS } \\
\text { prevention. }\end{array}$ \\
\hline
\end{tabular}




\begin{tabular}{|c|c|c|c|c|}
\hline $\begin{array}{l}\text { "Comprehensive } \\
\text { Sexual Education" } \\
\text { "Secondary } \\
\text { School Education" } \\
\text { "HIVIAIDS" } \\
\text { "Intervention } \\
\text { Review" } \\
\text { "Sexual Risk } \\
\text { Behavior" }\end{array}$ & $\begin{array}{l}\text { Ybarra, M.L. } \\
\text { Bull, S.S. } \\
\text { Prescott, T.L. } \\
\text { Birungi, R. }\end{array}$ & 2014 & $\begin{array}{l}\text { Acceptability } \\
\text { and feasibility of } \\
\text { CyberSenga: an } \\
\text { Internet-based } \\
\text { HIV-prevention } \\
\text { program for } \\
\text { adolescents in } \\
\text { Mbarara, } \\
\text { Uganda. }\end{array}$ & $\begin{array}{l}\text { Study finds that } \\
\text { HIV-prevention } \\
\text { behaviors can be } \\
\text { positively affected } \\
\text { by internet } \\
\text { programs. While } \\
\text { the students in the } \\
\text { sample group } \\
\text { were somewhat } \\
\text { uncomfortable } \\
\text { with the level of } \\
\text { anatomical/behavi } \\
\text { oral detail that the } \\
\text { program provided, } \\
\text { its information did } \\
\text { not appear to be } \\
\text { confusing or } \\
\text { contradictory. The } \\
\text { students gave } \\
\text { feedback that they } \\
\text { would recommend } \\
\text { it to their peers. }\end{array}$ \\
\hline $\begin{array}{l}\text { "Comprehensive } \\
\text { Sexual Education" } \\
\text { "Youth Centers" } \\
\text { "HIVIAIDS" } \\
\text { "Intervention } \\
\text { Review" } \\
\text { "Sexual Risk } \\
\text { Behavior" }\end{array}$ & $\begin{array}{l}\text { Zuurmond, M.A. } \\
\text { Geary, R.S. } \\
\text { Ross, D.A. }\end{array}$ & 2012 & $\begin{array}{l}\text { The } \\
\text { effectiveness of } \\
\text { youth centers in } \\
\text { increasing use of } \\
\text { sexual and } \\
\text { reproductive } \\
\text { health services: } \\
\text { a systematic } \\
\text { review. }\end{array}$ & $\begin{array}{l}\text { This review } \\
\text { screened } \\
\text { evidence from } 17 \\
\text { youth center } \\
\text { programs. Youth } \\
\text { centers found to } \\
\text { serve small } \\
\text { numbers of the } \\
\text { population, mostly } \\
\text { adolescent men } \\
\text { and a significant } \\
\text { proportion older } \\
\text { than the target } \\
\text { age. Services } \\
\text { weren't widely } \\
\text { used nor were } \\
\text { they found to be } \\
\text { cost-effective. }\end{array}$ \\
\hline
\end{tabular}

Analysis 
The data was analyzed via a content analysis method and coded for the manifest content listed in the "indicators" column. The mention was not tallied, as this method was more a means of summarizing the topics of each journal article in order to assess the state of knowledge. Each program and its relative findings are described in order to better assess the research. The data collected indicates a dearth of research on the impact of missionary work as it relates to sexual behavior outcomes in adolescents. However, the research indicates that the efficacy of an educational intervention depends on how early and regularly it is given. The studies that reported the highest attitudinal and behavioral indicators were studies using scientifically rigorous intervention programs that allow adolescents to work with trained teachers and healthcare workers. Furthermore, the best outcomes appear to occur in communities who have access to healthcare providers and safe sexual resources, in addition to the education given. As one study mentioned- if an adolescent does not have access to condoms in the first place, their attitude measures about condoms are not the primary concern.

While some of these studies analyzed programs that were meant to educate about sexual abuse, few directly addressed the difficult, or more stigmatized, topics of sex work and LGBTQ identity. Many studies reported teacher and parent discomfort with implementing comprehensive sexual education programs in addition to lack of resources as reasons for poor intervention outcomes. The HIV/AIDS epidemic in sub-saharan Africa is the result of a wide variety of variables. It seems that even if comprehensive sexual education needs were adequately addressed, the need for healthcare is still a major concern. While some risky sexual behaviors are performed due to a poor or inadequate sexual education, others appear to arise out of poverty and lack of access to contraception. Furthermore, most of the studies did not rely on biomedical data. 
Self-reported attitudes from sociological surveys were the main types of articles that satisfied the search criteria. These search results provide helpful but limited information. In particular, information about health outcomes and interventions in the global south. We can extrapolate by assessing HIV/AIDS data from the region as well, however the gap persists. This gap is even more true for communities that rely primarily on religious leaders to provide information on sex and relationships.

Discussion

Comprehensive sexual education seems to produce the best results when given alongside legislative protections and healthcare labor. The larger HIV/AIDS crisis in sub-saharan Africa may be the result of a region with a triadic lack of comprehensive sexual education, legislative protections for women/LGBTQ people/sex workers, and healthcare resources. If we were to rely exclusively on data from PubMed to assess comprehensive sexual education's relationship to the HIV incidence rate in sub-saharan Africa, we would be misled about the many variables involved in the issue. The construction of the search algorithm could also be to blame for this dearth, however the algorithm was constructed through a trial and error process with the goal of seeking out information specifically on HIV incidence rate and sexual education pedagogy in sub-saharan Africa. Search parameters were altered numerous times in order to find the articles that were most relevant to the research inquiry. However, there is a theoretical harm in narrowing the number of articles via the addition of search terms. It is possible that certain articles were not caught within the algorithm and if that is the case, then the overall assessment of the results as it pertains to the research inquiry may be incomplete or somewhat inaccurate. However, given the information available on PubMed, extracted with what the author believes to 
be the appropriate methodology, we can parse the current state of knowledge on sexual education pedagogy and HIV incidence rate within this database. PubMed was chosen as a database due to its credibility and usage by accredited United States-based institutions. The state of knowledge existent in PubMed is somewhat representative of the current level healthcare research being conducted in regard to this topic. The lack of clinical studies is a major concern, as it shows that the relationship between education and incidence rate is studied mostly on a sociological level. One can assume that if clinical studies existed on this topic, they would likely be included in PubMed as a medical research database. Therefore, we can assume that little research is being conducted in regard to this topic that isn't sociological research.

In order to explore why this dearth exists and also how it can be effectively addressed, we can use a sociological explanation. As a continent, Africa is oppressed within a global system. It follows then that African nations might have a more rigid adherence to social systems of oppression such as sexism and homophobia as a means of competing for access to its minimal infrastructural resources. It is beneficial to western neocolonial powers to exploit Africa for wealth, but is it also beneficial to promote a culture of individualism and patriarchy? Potentially, yes. Further dividing and subjugating impoverished nations both culturally and economically serves to suppress them for maximum wealth extraction. Healthcare, like education, is a political infrastructure. There will always be a non-zero probability need for both healthcare and education in any society. Limiting access to these fundamental infrastructures causes great social harm and likely, the spread of disease. Therefore, infrastructural resources such as comprehensive sexual education are a public health issue. The findings of this review indicate that the HIV/AIDS crisis in sub-saharan Africa has multiple causes, but the roots of its severity 
come down to the way Africa has been systematically stripped of wealth under colonization and then through neocolonialism. While nonprofit organizations are conducting monumental efforts to alleviate the public health burden in these countries, the need for nonprofit work in the first place signifies a larger problem with unsustainability and systemic violence in the era of globalization.

Philip McMichael also critiques efforts to humanize development by usage of transnational banks and certain NGOs. Pulling from Karl Polanyi’s distinction between a formal and substantive economy, McMichael's work urges us to consider examples of a substantive economy where equality is realized through "strategic sovereignty and representational power." (Costa \& McMichael ${ }^{2017}$ ) This method of parsing the development crisis has an epistemological component that lends itself well to describing public health concerns in sub-saharan Africa. McMichael talks about the poverty of the global order through Polanyi's division. We have formal economies or classical economics which depict the laws of rational action and decision making in scarcity. However, formal economies fail to take into account the structural conditions people must adapt to in order to survive within society. Substantive economics focuses on how people navigate wealth distribution in societies with deterministic social institutions. Extrapolating from this, both materially and epistemologically to a globalized scale, McMichael argues that countries on the periphery of the commodity chains are trapped in a development crisis. Taking the concept of a development crisis through the lens of public health, this analysis holds a number of troubling implications. Namely, that it is most profitable for the western world to continue extracting wealth and labor from the global south, but neglecting to formally address their health concerns. (McMichael ${ }^{2017}$ ) It is profitable for major transnational pharmaceutical 
companies to find willing test subjects in the global south, but it is not profitable to treat certain prevalent diseases for free. This speaks to a larger problem of monetizing healthcare to the extent that we have in globalization. Despite these large markets of sick people in need of healthcare labor and medicine, we fail to provide them with adequate support. Meanwhile, it is the very legacy of colonialism and neocolonialism that created our system of stratified global wealth in the first place. The wealth of core countries is built on the back of the global south's labor. It is undeniable then that core countries play a role in the health outcomes of the global south, the social determinants, and the lack of adequate infrastructure. (McMichael ${ }^{2017}$ ) From there, we have to ask ourselves an important question about global health, our own biology, and the environmental conditions we influence. That question is; what will the future look for us like under a system where large portions of the global population are not adequately treated for disease and infirmity? Are we prepared to face that future?

The results of this development crisis are complex and the following suggestions may only provide partial, though necessary, aid to these countries. The need for incidence rate to be closely monitored requires funding for laboratory science and hospital development. Public health campaigns promoting regular testing for HIV should be continually promoted. Comprehensive sexual education in secondary education requires both funding and adequate training in order to be implemented. Additionally, legislative protections that prevent missionary nonprofits from promoting harmful pseudoscience should be considered. Community health centers developed as safe spaces for poor women, sex workers, and LGBTQ people should be funded. Education speaking explicitly about HIV and bullying protection for HIV-positive students in schools would be another major step forward. There are numerous ways to address 
this problem, both through additional research and through public health funding. The sociological reports discuss the need for legislation and biomedical intervention, but it seems that the additional funding and research is unavailable. Addressing the need for additional biomedical research and healthcare funding in sub-saharan Africa is a major task in and of itself. While the UN Population Fund and The Bill \& Melinda Gates Foundation have provided some of the funds and labor to address these issues, more funding and even structural interventions are still needed. While the dearth of research in PubMed could signify an ineffective search algorithm, given the sociopolitical context of the issue, it seems more likely that the itself is very sparse.

\section{Limitations}

This review was limited to one database and only sampled articles published within the past ten years. This means that the review only depicts the current state of knowledge archived by PubMed. There are possibly studies that fall outside of the narrow search terms or are archived on exclusively on other databases.

\section{Bibliography}

Uganda court annuls anti-homosexuality law. BBC News. http://www.bbc.com/news/world-africa-28605400. Published August 1, 2014. Accessed June 14, 2017.

Conrad P, Leiter V. The Sociology of Health \& Illness: Critical Perspectives. New York, NY: Worth Publishers; 2013. 
Costa DD, Mcmichael P. The Poverty of the Global Order. Globalizations. 2007;4(4):588-602. doi:10.1080/14747730701695851.

Jacobsen KH. Introduction to global health. Burlington, MA: Jones \& Bartlett Learning; 2014.

The Library of Congress: Global Legal Research Directorate. Laws on Homosexuality in African Nations.; 2014.

Marmot M. The Health Gap: The Challenge of an Unequal World. London: Bloomsbury; 2016.

McMichael P. Development and Social Change: A Global Perspective. Los Angeles: SAGE; 2017.

Missionaries of Hate. Vanguard Television; 2010.

http://topdocumentaryfilms.com/missionaries-of-hate/.

Petti CA, Polage CR, Quinn TC, Ronald AR, Sande MA. Laboratory Medicine in Africa: A Barrier to Effective Health Care. Clinical Infectious Diseases. 2006;42(3):377-382. doi:10.1086/499363. 
Schell CO, Reilly M, Rosling H, Peterson S, Ekström AM. Socioeconomic determinants of infant mortality: A worldwide study of 152 low-, middle-, and high-income countries.

Scandinavian Journal of Public Health. 2007;35(3):288-297. doi:10.1080/14034940600979171.

Statistics. UNICEF. https://data.unicef.org. Published December 31, 2013. Accessed May 19, 2017.

The Joint United Nations Programme on HIV and AIDS. The UNAIDS Prevention Gap Report.; 2016.

United Nations Population Fund. New York: UNFPA; 1995.

Weber M, Giddens A, Parsons T. The Protestant Ethic ; Spirit of Capitalism. London: Routledge; 1992

World Bank Open Data. The World Bank. http://data.worldbank.org. Accessed May 16, 2017. 